Article

\title{
Therapeutic Effect of Rumex japonicus Houtt. on DNCB-Induced Atopic Dermatitis-Like Skin Lesions in Balb/c Mice and Human Keratinocyte HaCaT Cells
}

\author{
Hye Ryeon Yang ${ }^{1}$, Hyunkyoung Lee ${ }^{1}$, Jong-Hyun Kim ${ }^{1,2}$, Il-Hwa Hong ${ }^{1,2}$, Du Hyeon Hwang ${ }^{1}$, \\ Il Rae Rho ${ }^{3}$, Gon Sup Kim ${ }^{1}$ (D) Euikyung Kim ${ }^{1,2}$ and Changkeun Kang ${ }^{1,2, *(\mathbb{D})}$ \\ 1 College of Veterinary Medicine, Gyeongsang National University, Jinju 52828, Korea; \\ 2015210922@gnu.ac.kr (H.R.Y.); leehy@gnu.ac.kr (H.L.); jkim@gnu.ac.kr (J.-H.K.); \\ ihhong@gnu.ac.kr (I.-H.H.); pooh9922@hanmail.net (D.H.H.); gonskim@gnu.ac.kr (G.S.K.); \\ ekim@gnu.ac.kr (E.K.) \\ 2 Institutes of Animal Medicine, Gyeongsang National University, Jinju 52828, Korea \\ 3 Institutes of Agriculture and Life Science, Gyeongsang National University, Jinju 52828, Korea; \\ irno12@gnu.ac.kr \\ * Correspondence: ckkang@gnu.ac.kr; Tel.: +82-55-772-2364; Fax: +82-55-772-2349
}

Received: 29 January 2019; Accepted: 4 March 2019; Published: 7 March 2019

\begin{abstract}
Rumex japonicus Houtt. (RJ) is traditionally used in folk medicines to treat patients suffering from skin disease in Korea and other parts of East Asia. However, the beneficial effect of RJ extract on atopic dermatitis (AD) has not been thoroughly examined. Therefore, this study aimed to investigate the anti-inflammatory effects of RJ on AD in vitro and in vivo. Treatment with RJ inhibited the phosphorylation of mitogen-activated protein kinase (MAPK) as well as the activation of nuclear factor-kappa B (NF- $\mathrm{kB}$ ) in tumor necrosis factor- $\alpha$ (TNF- $\alpha$ ) stimulated in HaCaT cells. The five-week-old Balb/c mice were used as an AD-like mouse model by treating them with 1-chloro-2, 4-dinitrobenzene (DNCB). Topical administration of RJ to DNCB-treated mice significantly reduced clinical dermatitis severity, epidermal thickness, and decreased mast cell and eosinophil infiltration into skin and ear tissue. These results suggest that RJ inhibits the development of AD-like skin lesions by regulating the skin inflammation responses in $\mathrm{HaCaT}$ cells and $\mathrm{Balb} / \mathrm{c}$ mice. Thus, RJ may be a potential therapeutic agent for AD.
\end{abstract}

Keywords: Rumex japonicus Houtt.; atopic dermatitis; DNCB; skin lesion; MAPK; NF-кB; TNF- $\alpha$

\section{Introduction}

Atopic dermatitis (AD) is a multifactorial skin disease, with complex interactions. Various factors, including immunological abnormalities, contribute to the pathogenesis and development of AD [1]. The early onset of $\mathrm{AD}$ in infancy results in it being the most prevalent chronic skin disorder in childhood and can affect individuals throughout their lifetimes [2]. The common symptoms of AD include dry, inflamed skin, intense pruritis, itching and skin hypersensitivity. In some instances, AD can also cause recurring rashes, persistent scratching, erythematous plaques, and small bumps like blisters that may leak extracellular fluid. In chronic severe cases, AD causes sleep disturbance which may leads to insomnia, psychological and emotional distress, and low quality of life [3-5].

The current treatment for AD involves topical steroids, emollients and oral anti-histamines as the first-line therapy, but many patients are still worried about the long term use of these agents, and side-effects are frequently observed [2,6-8]. As a result, the importance of developing novel therapeutic agents for AD has increased recently. Natural products, such as astaxanthin and red 
ginseng, are increasingly being implicated in the regulation of inflammatory cytokines and chemokines in the development of AD-like skin lesions $[9,10]$.

Rumex japonicus Houtt. (RJ) is a perennial herb that is distributed throughout Japan, Korea, and China. It contains a large number of anthraquinones, flavonoids and triterpenoids, and has potential clinical applications in skin disease due to its antioxidant activity [11]. We previously reported that RJ had a hair growth-promoting effect via mitogen-activated protein kinases (MAPKs) and Wnt/ $\beta$-catenin pathways in human keratinocytes (HaCaT) and mice [12]. Although RJ has been showed to have pharmacological activity in hair growth, the effect of RJ as an anti-inflammatory agent for AD remains poorly understood. This study was designed to assess the anti-AD effects of RJ on TNF- $\alpha$-induced immune responses in $\mathrm{HaCaT}$ cells and a 1-chloro-2, 4-dinitrobenzene (DNCB) application mouse model.

\section{Materials and Methods}

\subsection{Materials}

Bovine serum albumin (BSA), Dulbecco's modified Eagle's Medium (DMEM), Fetal bovine serum (FBS), penicillin, streptomycin and trypsin were purchased from Gibco-BRL (Grand Island, NY, USA). Dimethyl sulfoxide (DMSO) and 3-(4,5-dimethylthiazol-2-yl)-2,5 diphenyltetrazolium bromide (MTT) were obtained from Sigma-Aldrich Inc. (St. Louis, MO, USA). Antibodies for phospho-Akt (Ser473), phospho-ERK, phospho-p38, phosphor-IкB $\alpha$, NF-kB p65, Lamin B1 and GAPDH were obtained from Cell Signaling Technology (Beverly, MA, USA). TNF- $\alpha$ was purchased from R\&D Systems (Tokyo, Japan). All other reagents used were of the purest grade available.

\subsection{Preparation of Rumex japonicus Houtt Extract}

The dried roots of Rumex japonicus Houtt. (RJ) were provided by Keratin Korea (Busan, Korea). The roots were washed 3 times with tap water to remove impurities and dried at room temperature, then stored at $4{ }^{\circ} \mathrm{C}$ until use. Dried roots were ground into powder with a grinder and extracted 3 times with $95 \%$ ethanol at $25^{\circ} \mathrm{C}$ for 3 days, after which the extract was filtered through the Advantech No. 3 filter paper (Cole-Parmer, Osaka, Japan). The filtered liquid was evaporated using a rotary vacuum evaporator (Tokyo Rikakikai Co., Ltd., Tokyo, Japan). The final step was lyophilization under vacuum to dryness.

\subsection{Cell Culture and Cell Viability}

Cell viability was measured by MTT assay. Briefly, human keratinocyte cells (HaCaT) were maintained in DMEM with $10 \%$ FBS and $100 \mu \mathrm{g} / \mathrm{mL}$ penicillin-streptomycin at $37^{\circ} \mathrm{C}$ in a $5 \% \mathrm{CO}_{2}$ humidified incubator. HaCaT cells were plated at a density of $4 \times 10^{4}$ cells/well in 24 -well plates and cultured overnight in growth DMEM media. Cells were removed by gentle washing with fresh culture medium and treated with various concentrations of RJ and incubation for 24,48 and $72 \mathrm{~h}$. MTT solution $(5 \mathrm{mg} / \mathrm{mL})$ was then added to each well and incubated for an additional $3 \mathrm{~h}$ at $37^{\circ} \mathrm{C}$. Finally, DMSO was added to solubilize the formazan salt and the amount of formazan generated was determined by measuring the optical density (OD) at $540 \mathrm{~nm}$ using a GENios ${ }^{\circledR}$ microplate spectrophotometer (PowerWaveTMXS, BioTek Instruments, Inc., Winooski, VT, USA).

\subsection{Western Blot Analysis}

Cells were incubated at a density of $5 \times 10^{4}$ cells/well in 6-well plates for $24 \mathrm{~h}$ in complete DMEM. After the adaptation process, cells were treated with RJ for $30 \mathrm{~min}$, and then stimulated with TNF- $\alpha$ $(10 \mathrm{ng} / \mathrm{mL})$ for $30 \mathrm{~min}$ in serum-free culture medium. After cells had been washed with cold PBS, the treated cells were collected by scraping with $300 \mu \mathrm{L}$ of RIPA buffer (TransLab, Daejeon, Korea) containing protease inhibitor. Lysates were separated using 10\% SDS-polyacrylamide gel and then transferred to PVDF membranes (Bio-Rad, Hercules, CA, USA). Western blot were probed with specific 
primary antibodies overnight at $4^{\circ} \mathrm{C}$. Following incubation with horseradish peroxidase-conjugated secondary antibody (Bethyl Laboratories Inc., Montgomery, AL, USA) for $1 \mathrm{~h}$ at room temperature, the blots were visualized using an enhanced chemiluminescence method (ECL, Amersham Biosciences, Buckinghamshire, UK) and analyzed using ChemiDoc XRS (Bio-Rad, CA, USA). Densitometry analysis was performed with a Hewlett-Packard scanner and Image Lab software.

\subsection{Experimental Animals}

Five-week-old female Balb/c mice were purchased from Samtako Inc. (Osan, Korea) and cared for in Gyeongsang National University laboratory animal research center. Mice were housed in cages under standard conditions with food/water available ad libitum and a $12 \mathrm{~h}$ light/dark cycle. The room temperature and humidity were $23 \pm 2{ }^{\circ} \mathrm{C}$ and $35-60 \%$, respectively. The animal study protocol used in this work was approved by the Institutional Animal Care and Use Committee of Gyeongsang National University, and the animal study protocol number was GNU-160623-M0015.

\subsection{Experimental Study with RJ for $A D$}

A total of 25 mice were randomly divided into five groups ( $n=5$ per group): group 1, vehicle-treated group (Sham); group 2, vehicle with DNCB (Control); group 3 and 4, $4 \mathrm{mg} / \mathrm{mL}$ and $8 \mathrm{mg} / \mathrm{mL}$ RJ with DNCB, respectively; group 5, dexamethasone with DNCB group (positive control). The doses of RJ were selected considering that there was no clinical pathology in our preliminary toxicity study (data not shown). Atopic dermatitis was induced in the mice by treatment with 1-chloro, 2,4-dinitrochlorobenzene (DNCB). On day 0 , the hair on the dorsal skin of the mice in all groups was shaved using an electric razor. During days 1-3, $200 \mu \mathrm{L}$ of $0.5 \%$ DNCB solution (dissolved in a 3:1 mixture of acetone and olive oil) was applied once daily to the dorsal skin and ear of the mice for three days in the control, RJ, and dexamethasone groups. The sham group received a vehicle treatment (only acetone/olive oil). After this initial sensitization treatment, RJ was applied topically to the skin and ears of the mice every day for 3 weeks. The positive control of dexamethasone treatment was applied through a $1.5 \mathrm{mg} / \mathrm{kg}$ I.P injection three times per week. Animals were sacrificed at experimental day 35. The exact experimental schedule is illustrated in Figure 1.

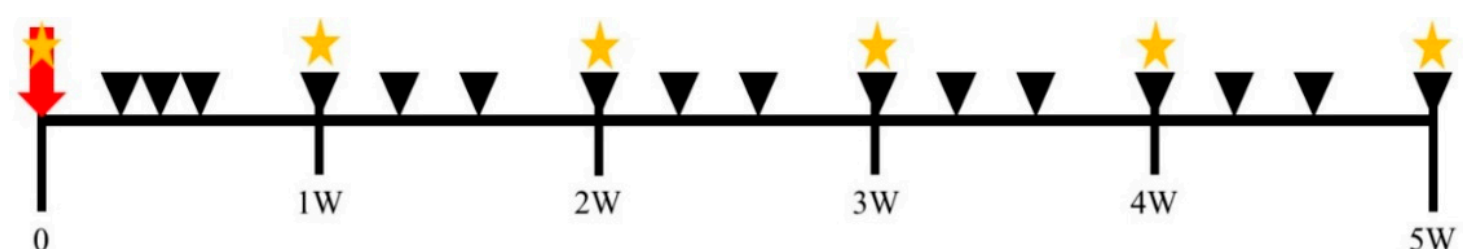

0

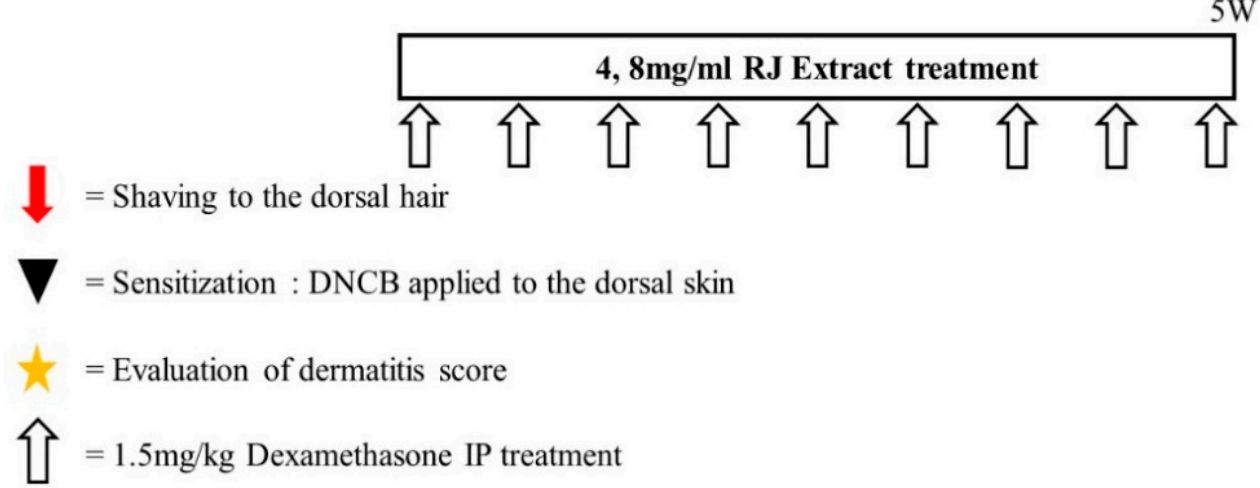

Figure 1. Experimental schedule for the induction of atopic dermatitis (AD) lesions. Mice were divided into five groups ( $n=5$ per group). To induce AD-like immunological and skin lesions, DNCB was applied to the dorsal skin and ears. 


\subsection{Measurement of Ear Thickness and Organ Weight}

Ear thickness was measured with a micrometer on the day of sacrifice. The micrometer was applied near the tip of the ear just distal to the cartilaginous ridges, and the thickness was recorded in micrometers. Weights of lymph nodes and spleen were measured with an electronic balance.

\subsection{Histopathological Studies}

The skin and ear lesions were sliced and tissue slices were fixed in $10 \%$ buffered-neutral formalin for $24 \mathrm{~h}$. The fixed tissue slices were embedded in paraffin wax, sectioned, deparaffinized, and rehydrated using standard techniques. Sections $5 \mu \mathrm{m}$ thick were subjected to hematoxylin and eosin (H\&E) staining and toluidine blue staining for the detection of various inflammatory cells. Histopathological changes were examined by light microscopy. An arbitrary scope was given to each microscopic field viewed at a magnification of 100 (skin) and 200 (ear).

\subsection{Statistical Analysis}

The results are expressed as mean \pm standard deviation (S.D.). One-way analysis of variance (ANOVA) was used to evaluate the significance of difference between the two mean values. ${ }^{*} p<0.05$ and ${ }^{* *} p<0.01$ were considered to be statistically significant.

\section{Results}

\subsection{The Optimal Treatment Concentration of RJ Extract on HaCaT Cells}

To determine the optimal treatment concentration of RJ on HaCaT cells, an MTT assay was performed. The RJ extract had no cytotoxic effect at a concentration of $50 \mu \mathrm{g} / \mathrm{mL}$ for $24 \mathrm{~h}$, but as shown in Figure 2A, the viability of cells treated with an RJ concentration of $1600 \mu \mathrm{g} / \mathrm{mL}$ declined by about $44 \%$ after $24 \mathrm{~h}\left(\mathrm{IC}_{50}\right.$ approximately $\left.1150.72 \mu \mathrm{g} / \mathrm{mL}\right)$. We also measured the effect of $\mathrm{RJ}$ in the presence or absence of TNF- $\alpha$. RJ had no cytotoxic effect at concentrations of up to $50 \mu \mathrm{g} / \mathrm{mL}$ with $10 \mathrm{ng} / \mathrm{mL}$ TNF- $\alpha$ stimulation in the HaCaT cells (Figure 2B). Therefore, we used 25 and $50 \mu \mathrm{g} / \mathrm{mL}$ of RJ with $10 \mathrm{ng} / \mathrm{mL}$ of TNF- $\alpha$ in our subsequent experiment.

\subsection{RJ Treatment Modulates TNF- $\alpha$ Induced Changes in MAPK Family and NF- $\kappa B$ Pathway of Proteins in HaCaT Cells}

To investigate the molecular mechanism of the anti-inflammatory activity of RJ in TNF- $\alpha$-stimulated keratinocytes, we first examined whether RJ inhibits the activation of mitogen-activated protein kinase (MAPK) and Akt signaling pathways. HaCaT cells were pretreated with RJ ( 25 and $50 \mu \mathrm{g} / \mathrm{mL}$ ) for $30 \mathrm{~min}$, followed by induction by TNF- $\alpha$ for $30 \mathrm{~min}$. We analyzed phosphorylation of ERK 1/2, p38, and Akt by Western blot. Dose-dependent RJ treatment inhibited the phosphorylation of p38, ERK $1 / 2$ and Akt in TNF- $\alpha$-stimulated cells (Figure 3A,B). Next, we examined the activation of NF- $\kappa \mathrm{B}$ and I $\kappa \mathrm{B} \alpha$ degradation in TNF- $\alpha$-stimulated HaCaT cells. In an unstimulated state, NF- $\kappa B$ was retained in the cytosol as an inactive complex with its inhibitory protein $\mathrm{I} \kappa \mathrm{B} \alpha$, which blocks the nuclear importing sequences of NF- $\mathrm{kB}$. The transcriptional activation of NF- $\mathrm{kB}$ was regulated by the phosphorylation of its functionally active subunit p65/RelA with serine 536 residue in its transcriptional activation domain [13]. The dose-dependent RJ treatment inhibited

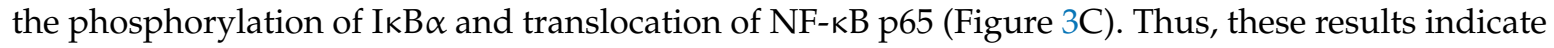
that RJ had an anti-inflammatory effect on the accumulation of allergic modulators by blocking MAPK, Akt and suppressing NF- $\mathrm{kB}$ activation. 

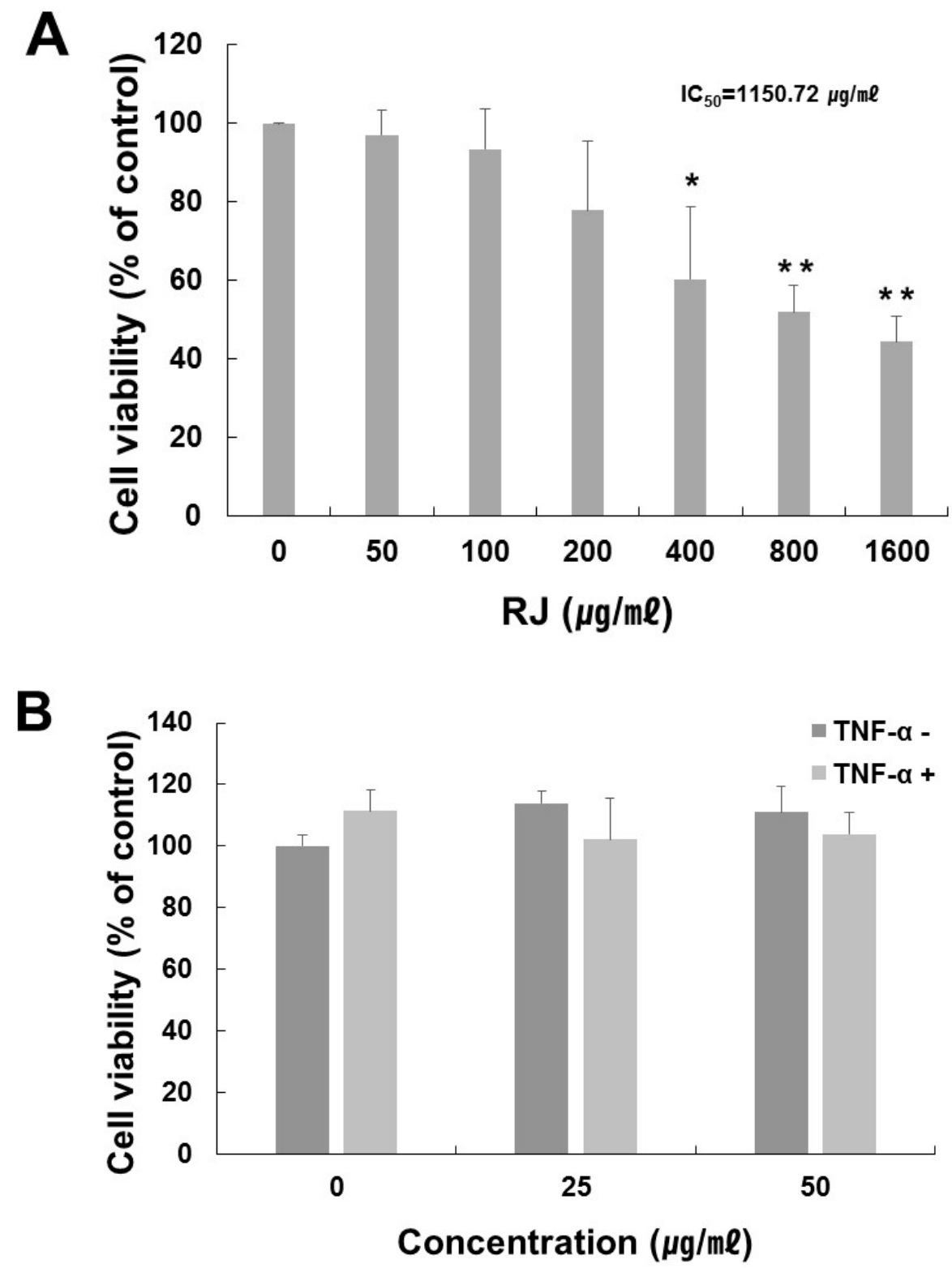

Figure 2. Cell viability of various treatment concentration of RJ on HaCaT cells. (A) HaCaT cells were treated with RJ at the indicated concentrations for $24 \mathrm{~h}$. (B) Cell viability of $\mathrm{RJ}(0,25,50 \mu \mathrm{g} / \mathrm{mL})$ with or without TNF- $\alpha(10 \mathrm{ng} / \mathrm{mL})$ in HaCaT cell. HaCaT cells were pretreated with 0,25 and $50 \mu \mathrm{g} / \mathrm{mL} \mathrm{RJ}$ for $30 \mathrm{~min}$ then stimulated with $10 \mathrm{ng} / \mathrm{mL}$ of TNF- $\alpha$ for $30 \mathrm{~min}$. Cell viability was then determined by MTT assay. The data shown are the mean \pm SD of three independent experiments. Significant difference from control group, ${ }^{*} p<0.05,{ }^{* *} p<0.01$.

\subsection{RJ Suppressed Clinical Severity of AD Skin Symptoms in DNCB-Induced Balb/c Mice}

To assess the effectiveness of RJ against AD-like skin lesions, Balb/c mice were treated by DNCB to cause $\mathrm{AD}$-like skin lesions, followed by treatment with RJ and dexamethasone, as described in Figure 1. As expected, the application of DNCB led to significant inflammation. As shown in Figure 4A, the repeated topical application of DNCB significantly increased ear thickness in the DNCB-treated group compared with the sham group. In addition, the RJ-treated group reduced ear thickness in a dose-dependent manner during the whole study period. Since AD often develops as a systemic immune response, it can affect the immune organs [14-17]. Therefore, we evaluated that weight of the lymph nodes and spleen was measured in the final week to examine whether the topical application of RJ provided an anti-AD effect in mice. The control group results showed an elevation of lymph node 
and spleen weight compared with the sham group. The RJ treatment group showed a dose-dependent inhibition of lymph node weight (Figure 4B). In addition, the spleen weight was slightly decreased after RJ treatment (Figure $4 \mathrm{C}$ ). Thus, these results show that the topical application of RJ can have anti-AD effects.

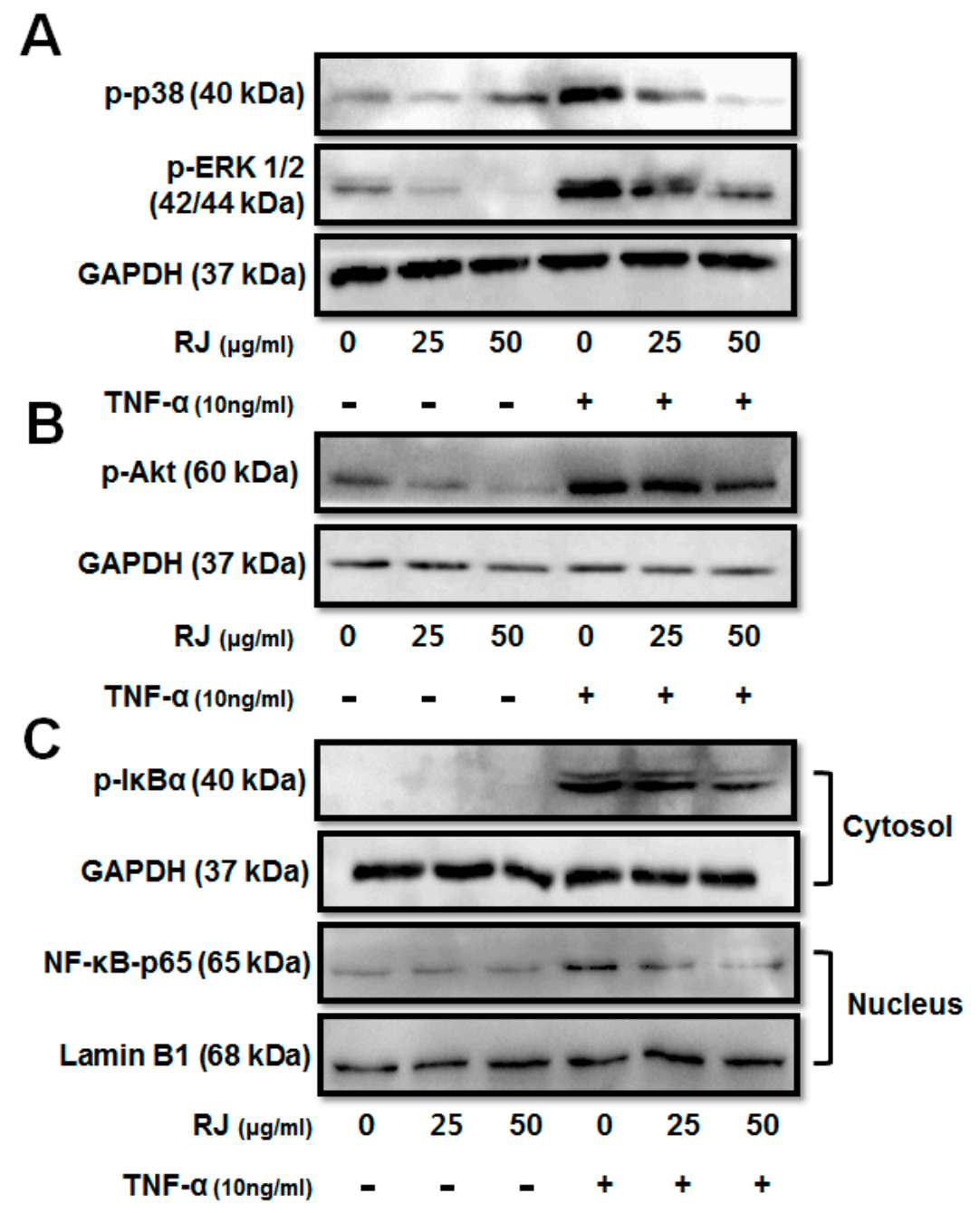

Figure 3. The inhibitory effect of RJ on TNF- $\alpha$-stimulated mitogen-activated protein kinases (MAPK) and nuclear factor-kappa B pathways. HaCaT cells were pretreated with 0,25 and $50 \mu \mathrm{g} / \mathrm{mL}$ RJ for $30 \mathrm{~min}$ then stimulated with $10 \mathrm{ng} / \mathrm{mL}$ of TNF- $\alpha$ for $30 \mathrm{~min}$. (A) MAPKs including ERK1/2, p38 were assessed by Western blot analysis. (B) Akt phosphorylation was inhibited in a dose-dependent manner after TNF- $\alpha$ stimulation of the HaCaT cells. (C) Inhibition of NF- $\mathrm{KB}$ pathway in TNF- $\alpha$ stimulated HaCaT cells was assessed by Western blot analysis. The data shown are the mean \pm SD of three independent experiments.

\subsection{Effect of RJ on AD-Like Skin Lesion in Mice}

AD increased skin thickness and excessive lymphocyte infiltration into the dermis. The skin and ear was stained with H\&E and toluidine blue to examine whether RJ improves AD-like skin pathogenesis. H\&E staining revealed that the control group drastically increased the thickness of both the epidermal and dermal tissues, whereas the RJ treatment group significantly ameliorated these changes compared with the control group, especially for epidermal tissue (Figure 5A). Moreover, toluidine blue staining indicated a prominent number of mast cells in the dermal area, whereas the RJ treatment group saw a dose-dependent decrease in mast cell numbers (Figure 5B). Thus, these findings contribute to a better understanding of the pathogenesis of AD-like skin lesion in mice. 
A

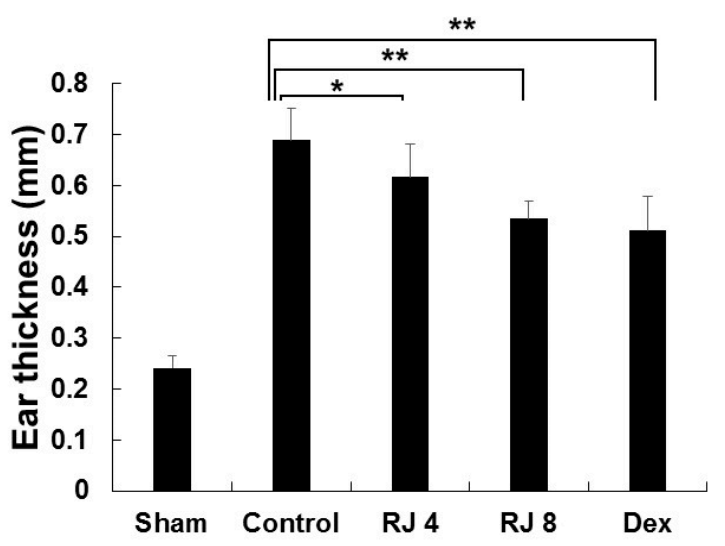

B
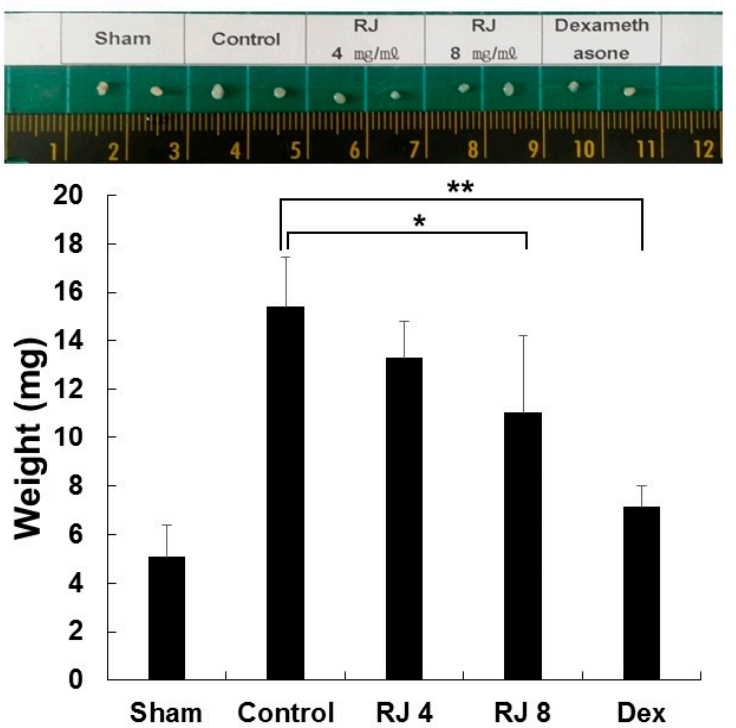

C
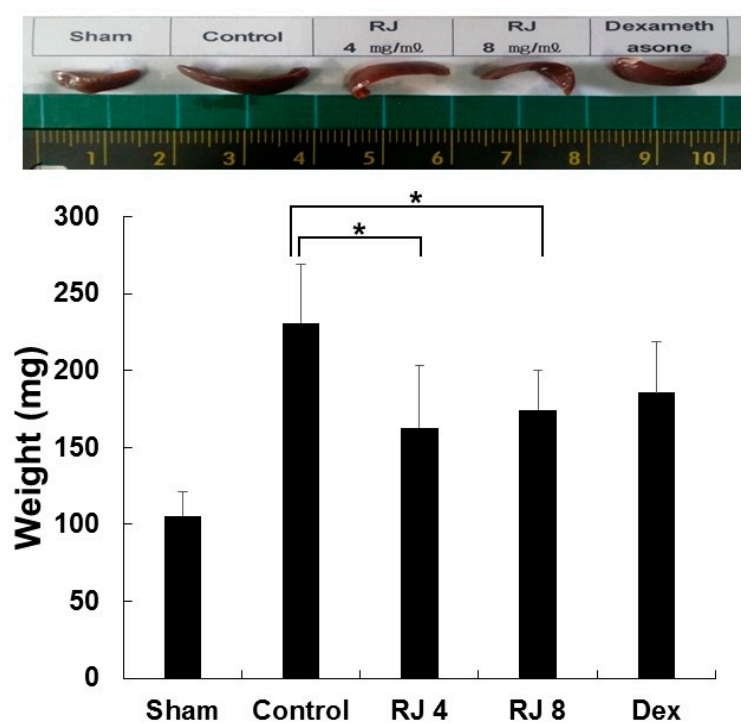

Figure 4. Inhibitory effects of RJ on DNCB-induced AD skin symptoms in Balb/c mice. The mice were divided into five groups: Vehicle (Sham), DNCB + vehicle (Control), DNCB + RJ $4 \mathrm{mg} / \mathrm{mL}$ (RJ 4), $\mathrm{DNCB}+\mathrm{RJ} 8 \mathrm{mg} / \mathrm{mL}$ (RJ 8), positive control (DEX). (A) Ear thickness was measured with a micrometer. Five mice were used per group. $(\mathbf{B}, \mathbf{C})$ Organ sizes were compared by photographic images. Organ and whole-body weight of five mice per group were measured. Five mice were used per group. The data shown are the mean $\pm \mathrm{SD}$ of three independent experiments. Significant difference from control group, ${ }^{*} p<0.05,{ }^{* *} p<0.01$ 


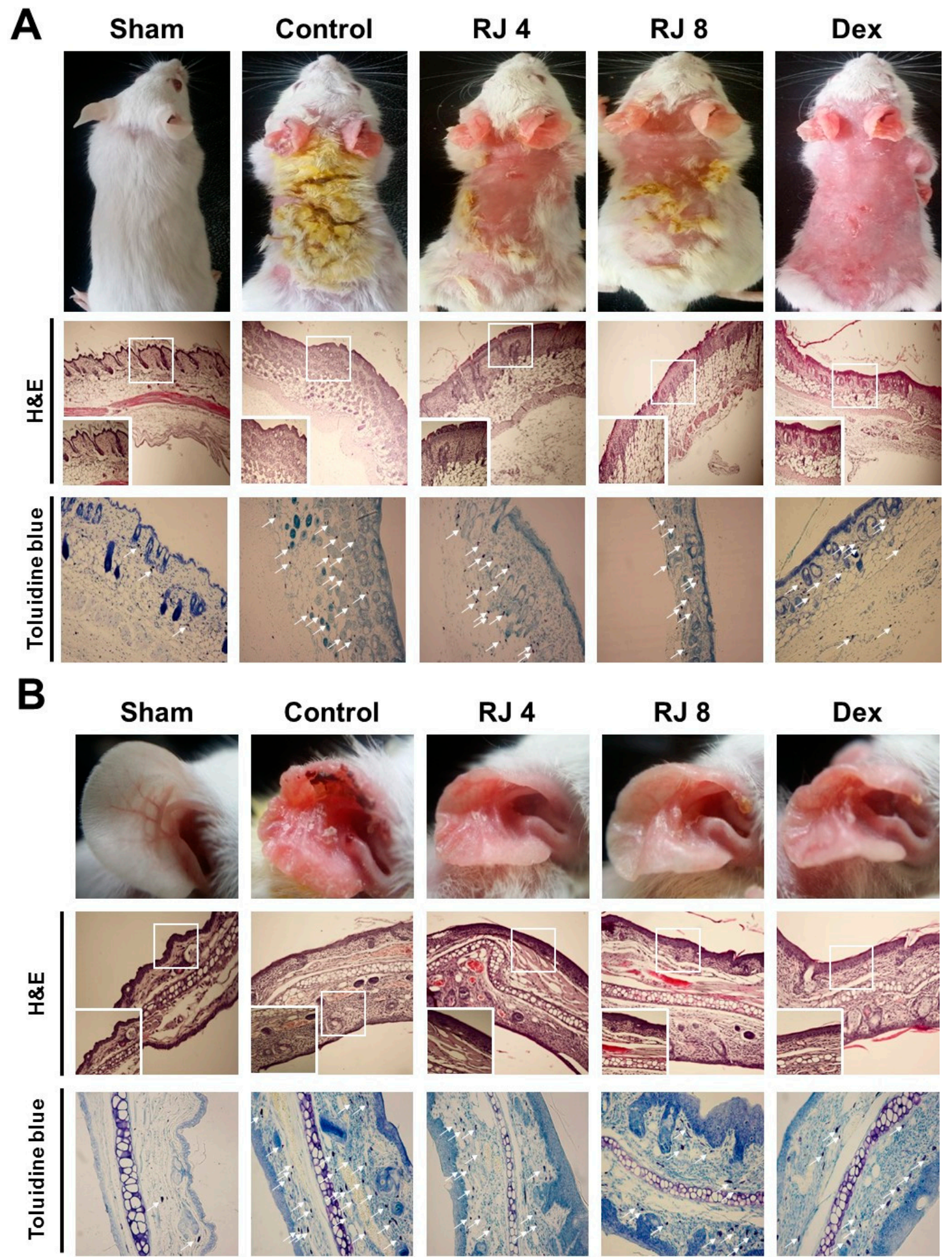

Figure 5. Effect of RJ on histological changes of the dorsal skin and ear lesions. (A,B) Skin and ear lesions were removed and fixed in 10\% formaldehyde solution. Skin sections were cut and stained with hematoxylin and eosin and toluidine blue. The immune cells (arrows) are indicated. Photographs were taken under a regular light microscope at a magnification of $100 \times$ (skin), $200 \times$ (ear). Five mice were used per group.

\section{Discussion}

The biological properties and health benefits of Rumex japonicus Houtt. (RJ) have been studied intensively over the past three decades on a variety of actions, including anti-oxidant, anti-microbial, 
anti-tumor, anti-inflammatory and anti-allergic effects [12,18-20]. The curative effects of RJ on skin disease and its complications seems to be related to its inhibition of T-helper 2 cell response [21]. Although the anti-allergic effects of RJ have already been reported, the mechanistic understanding of its pharmacological roles for atopic dermatitis is poorly elucidated. The principal finding of the present study is that RJ regulates the inhibition of MAPKs and NF-KB activation in TNF- $\alpha$ induced HaCaT cells and attenuates the development of DNCB-induced atopic dermatitis lesions in Balb/c mice.

Keratinocytes such as $\mathrm{HaCaT}$ cells play pivotal roles in skin disease and are commonly used for the in vitro testing of anti-inflammatory skin drugs [22]. Stimulation of keratinocytes by TNF- $\alpha$ leads to activation of various signaling pathways that involve MAPKs, Akt, and NF-KB [23]. One of the most extensively investigated intracellular signaling cascades involved in pro-inflammatory responses are the MAPK pathways [24]. MAPK pathways fall into several different subgroups, including ERK1/2, p38 and JNK. They are important signal transducers for cell survival and can regulate several cellular processes including proliferation, differentiation, survival and apoptosis. MAPKs are also involved in the inflammatory cytokine network. ERK1/2 belongs to the MAPK family and is crucial in the control of cell growth, cell differentiation and cell survival, and p38 acts as a key component in the induction of inflammation and immune system disorders [25]. We conducted experiments to explore the effects of RJ on the TNF- $\alpha$-induced expression of MAPK in HaCaT cells. Treatment of TNF- $\alpha$ significantly enhanced the phosphorylation of ERK and p38 expression. In contrast, treatment with RJ significantly inhibited the expression of ERK and p38 signal in TNF- $\alpha$-stimulated HaCaT cells.

Akt activity increases throughout the entire process of skin disease [26] and can activate the transcription factor NF- $\mathrm{kB}$ [27]. It has been suggested that the Akt pathway contributes to the activation of NF- $\kappa B$ through the phosphorylation of I $\mathrm{B} \alpha$ [27]. Recent findings indicate that TNF- $\alpha$ can activate $\mathrm{NF}-\mathrm{kB}$, which is responsible for the expression of pro-inflammatory cytokines [28]. Upon this cytokine stimulus, the IKB proteins are phosphorylated and degraded, which allows NF- $\mathrm{KB}$ to translocate into the nucleus where it can bind to specific promoter regions of target genes and activate the expression of inflammatory cytokine genes. Thus, the inhibition of NF-kB activation has been suggested as an anti-inflammatory strategy in AD [1,28]. As shown in our data, Akt activity was significantly reduced, preventing phosphorylation through treatment with RJ. Furthermore, RJ inhibited the degradation of I $\mathrm{B} \alpha$ and the nuclear localization of NF- $\kappa \mathrm{B}$.

Mouse models of $\mathrm{AD}$ allow the in-depth investigation of pathogenesis for allergic skin inflammation. Since the description of the Nc/Nga mouse as the first AD model in 1997, a number of mouse models have been developed [29]. From these mouse models, we selected the DNCB-induced mouse model due to its simplicity and histological characteristics. Repeated topical application of DNCB on the skin of mice induced many of the histopathological symptoms of AD within a month. Experimental data show that the AD-like skin lesions induced by DNCB treatment were predominantly controlled by cellular immune responses [30-32]. We evaluated the effects of RJ skin severity and histopathological changes in DNCB-induced mice. Topical treatment with RJ for 3 weeks showed a dose-dependent and effective improvement in skin symptoms and reduced the thickness of dorsal skin and ear skin thickness in DNCB-induced mice. We also found that topical RJ treatment reduced lymph node and spleen weight after these increased as a result of DNCB-sensitization, which may be involved in immune activity. In addition, the topical administration of RJ attenuated the infiltration of inflammatory eosinophils and mast cells in the ears and skin. From these results, we confirmed the therapeutic effects of RJ in AD-like skin lesions. In addition, various immune cells have been identified in relation to the development of $\mathrm{AD}$.

In conclusion, the topical administration of RJ inhibits the development of DNCB-induced atopic dermatitis skin lesions in Balb/c mice. In addition, the results of the in vitro study showed that RJ suppressed the activation of ERK, p38, Akt and NF-kB in TNF- $\alpha$-stimulated HaCaT cells. Taken together, these results suggest that the topical application of RJ may be an effective alternative therapy for the management of AD. Further studies are needed to address the serum IgE, histamine, 
inflammatory cytokine and chemokine levels, and determine which components of RJ contribute to its efficacy in the treatment of inflammatory skin disease.

Author Contributions: C.K. conceived, designed and wrote the manuscript; H.R.Y. mainly performed the experiments and wrote original draft; H.L and D.H.H. performed the in vivo study; J.H.K, I.H.H. and I.R.R collected and analyzed all study data; G.S.K. and E.K. participated in focus group discussion, reviewed the study and manuscript.

Funding: This study was partly supported by grants from the National Research Foundation of Korea (NRF-2018R1D1A1B07043071).

Acknowledgments: This research manuscript was modified from Hye Ryeon Yang's master's degree thesis.

Conflicts of Interest: The authors declare no competing interest regarding the publication of this paper.

\section{References}

1. Choi, J.H.; Jin, S.W.; Park, B.H.; Kim, H.G.; Khanal, T.; Han, H.J.; Hwang, Y.P.; Choi, J.M.; Chung, Y.C.; Hwang, S.K.; et al. Cultivated Ginseng Inhibits 2,4-Dinitrochlorobenzene-Induced Atopic Dermatitis-Like Skin Lesions in NC/Nga Mice and TNF-A/IFN-Г-Induced TARC Activation in HaCaT Cells. Food Chem. Toxicol. 2013, 56, 195-203. [CrossRef] [PubMed]

2. Choi, J.H.; Park, B.H.; Kim, H.G.; Hwang, Y.P.; Han, E.H.; Jin, S.W.; Seo, J.K.; Chung, Y.C.; Jeong, H.G. Inhibitory Effect of Psidium Guajava Water Extract in the Development of 2,4-Dinitrochlorobenzene-Induced Atopic Dermatitis in NC/Nga Mice. Food Chem. Toxicol. 2012, 50, 2923-2929. [CrossRef] [PubMed]

3. Papier, A.; Strowd, L.C. Atopic Dermatitis: A Review of Topical Nonsteroid Therapy. Drugs Context 2018, 7, 212521. [CrossRef] [PubMed]

4. Carroll, C.L.; Balkrishnan, R.; Feldman, S.R.; Fleischer, A.B., Jr.; Manuel, J.C. The Burden of Atopic Dermatitis: Impact on the Patient, Family, and Society. Pediatr. Dermatol. 2005, 22, 192-199. [CrossRef] [PubMed]

5. Boccardi, D.; D'Auria, E.; Turati, F.; DI Vito, M.; Sortino, S.; Riva, E.; Cerri, A. Disease Severity and Quality of Life in Children with Atopic Dermatitis: PO-SCORAD in Clinical Practice. Minerva Pediatr. 2017, 69, 373-380. [PubMed]

6. Czarnowicki, T.; Krueger, J.G.; Guttman-Yassky, E. Novel concepts of prevention and treatment of atopic dermatitis through barrier and immune manipulations with implications for the atopic march. J. Allergy Clin. Immunol. 2017, 139, 1723-1734. [CrossRef] [PubMed]

7. Chia, B.K.; Tey, H.L. Systematic Review on the Efficacy, Safety, and Cost-Effectiveness of Topical Calcineurin Inhibitors in Atopic Dermatitis. Dermatitis 2015, 26, 122-132. [CrossRef] [PubMed]

8. D'Auria, E.; Banderali, G.; Barberi, S.; Gualandri, L.; Pietra, B.; Riva, E.; Cerri, A. Atopic Dermatitis: Recent Insight on Pathogenesis and Novel Therapeutic Target. Asian Pac. J. Allergy Immunol. 2016, 34, 98-108. [PubMed]

9. Kee, J.Y.; Jeon, Y.D.; Kim, D.S.; Han, Y.H.; Park, J.; Youn, D.H.; Kim, S.J.; Ahn, K.S.; Um, J.Y.; Hong, S.H. Korean Red Ginseng Improves Atopic Dermatitis-Like Skin Lesions by Suppressing Expression of Proinflammatory Cytokines and Chemokines in Vivo and in Vitro. J. Ginseng Res. 2017, 41, 134-143. [CrossRef] [PubMed]

10. Yoshihisa, Y.; Andoh, T.; Matsunaga, K.; Rehman, M.U.; Maoka, T.; Shimizu, T. Efficacy of Astaxanthin for the Treatment of Atopic Dermatitis in a Murine Model. PLoS ONE 2016, 11, e0152288. [CrossRef] [PubMed]

11. Vasas, A.; Orban-Gyapai, O.; Hohmann, J. The Genus Rumex: Review of Traditional Uses, Phytochemistry and Pharmacology. J. Ethnopharmacol. 2015, 175, 198-228. [CrossRef] [PubMed]

12. Lee, H.; Kim, N.H.; Yang, H.; Bae, S.K.; Heo, Y.; Choudhary, I.; Kwon, Y.C.; Byun, J.K.; Yim, H.J.; Noh, B.S.; et al. The Hair Growth-Promoting Effect of Rumex Japonicus Houtt. Extract. Evid. Based Complement. Altern. Med. 2016, 2016, 1873746. [CrossRef] [PubMed]

13. Kalra, N.; Bhui, K.; Roy, P.; Srivastava, S.; George, J.; Prasad, S.; Shukla, Y. Regulation of p53, Nuclear Factor $\mathrm{kB}$ and Cyclooxygenase-2 Expression by Bromelain through Targeting Mitogen-Activated Protein Kinase Pathway in Mouse Skin. Toxicol. Appl. Pharmacol. 2008, 226, 30-37. [CrossRef] [PubMed]

14. Arts, J.H.E.; Dröge, S.C.M.; Bloksma, N.; Kuper, C.F. Local Lymph Node Activation in Rats After Dermal Application of the Sensitizers 2,4-Dinitrochlorobenzene and Trimellitic Anhydride. Food Chem. Toxicol. 1996, 34, 55-62. [CrossRef] 
15. Kang, Y.M.; Lee, K.Y.; An, H.J. Inhibitory Effects of Helianthus Tuberosus Ethanol Extract on Dermatophagoides Farina Body-Induced Atopic Dermatitis Mouse Model and Human Keratinocytes. Nutrients 2018, 10. [CrossRef] [PubMed]

16. Lee, H.S.; Choi, E.J.; Lee, K.S.; Kim, H.R.; Na, B.R.; Kwon, M.S.; Jeong, G.S.; Choi, H.G.; Choi, E.Y.; Jun, C.D. Oral Administration of P-Hydroxycinnamic Acid Attenuates Atopic Dermatitis by Downregulating Th1 and Th2 Cytokine Production and Keratinocyte Activation. PLoS ONE 2016, 11, e0150952. [CrossRef] [PubMed]

17. O'Neill, C.A.; Monteleone, G.; McLaughlin, J.T.; Paus, R. The Gut-Skin Axis in Health and Disease: A Paradigm with Therapeutic Implications. Bioessays 2016, 38, 1167-1176. [CrossRef] [PubMed]

18. Jiang, L.; Zhang, S.; Xuan, L. Oxanthrone C-Glycosides and Epoxynaphthoquinol from the Roots of Rumex Japonicus. Phytochemistry 2007, 68, 2444-2449. [CrossRef] [PubMed]

19. Zhou, X.; Xuan, L.; Zhang, S. Study on the Chemical Constituents from Rumex Japonicus Houtt. Zhong Yao Cai 2005, 28, 104-105. [PubMed]

20. BELKIN, M.; FITZGERALD, D.B. Tumor-Damaging Capacity of Plant Materials. I. Plants used as Cathartics. J. Natl. Cancer Inst. 1952, 13, 139-155. [PubMed]

21. Lee, H.S.; Kim, S.K.; Han, J.B.; Choi, H.M.; Park, J.H.; Kim, E.C.; Choi, M.S.; An, H.J.; Um, J.Y.; Kim, H.M.; et al. Inhibitory Effects of Rumex Japonicus Houtt. on the Development of Atopic Dermatitis-Like Skin Lesions in NC/Nga Mice. Br. J. Dermatol. 2006, 155, 33-38. [CrossRef] [PubMed]

22. Pastore, S.; Lulli, D.; Potapovich, A.I.; Fidanza, P.; Kostyuk, V.A.; Dellambra, E.; De Luca, C.; Maurelli, R.; Korkina, L.G. Differential Modulation of Stress-Inflammation Responses by Plant Polyphenols in Cultured Normal Human Keratinocytes and Immortalized HaCaT Cells. J. Dermatol. Sci. 2011, 63, 104-114. [CrossRef] [PubMed]

23. Pastore, S.; Mascia, F.; Girolomoni, G. The Contribution of Keratinocytes to the Pathogenesis of Atopic Dermatitis. Eur. J. Dermatol. 2006, 16, 125-131. [PubMed]

24. Chun, K.S.; Keum, Y.S.; Han, S.S.; Song, Y.S.; Kim, S.H.; Surh, Y.J. Curcumin Inhibits Phorbol Ester-Induced Expression of Cyclooxygenase-2 in Mouse Skin through Suppression of Extracellular Signal-Regulated Kinase Activity and NF-kappaB Activation. Carcinogenesis 2003, 24, 1515-1524. [CrossRef] [PubMed]

25. Plotnikov, A.; Zehorai, E.; Procaccia, S.; Seger, R. The MAPK Cascades: Signaling Components, Nuclear Roles and Mechanisms of Nuclear Translocation. Biochim. Biophys. Acta 2011, 1813, 1619-1633. [CrossRef] [PubMed]

26. Segrelles, C.; Ruiz, S.; Santos, M.; Martinez-Palacio, J.; Lara, M.F.; Paramio, J.M. Akt Mediates an Angiogenic Switch in Transformed Keratinocytes. Carcinogenesis 2004, 25, 1137-1147. [CrossRef] [PubMed]

27. Kane, L.P.; Shapiro, V.S.; Stokoe, D.; Weiss, A. Induction of NF-kappaB by the Akt/PKB Kinase. Curr. Biol. 1999, 9, 601-604. [CrossRef]

28. Aggarwal, B.B. Signalling Pathways of the TNF Superfamily: A Double-Edged Sword. Nat. Rev. Immunol. 2003, 3, 745-756. [CrossRef] [PubMed]

29. Matsuda, H.; Watanabe, N.; Geba, G.P.; Sperl, J.; Tsudzuki, M.; Hiroi, J.; Matsumoto, M.; Ushio, H.; Saito, S.; Askenase, P.W.; et al. Development of Atopic Dermatitis-Like Skin Lesion with IgE Hyperproduction in NC/Nga Mice. Int. Immunol. 1997, 9, 461-466. [CrossRef] [PubMed]

30. Lee, J.H.; Jeon, Y.D.; Lee, Y.M.; Kim, D.K. The Suppressive Effect of Puerarin on Atopic Dermatitis-Like Skin Lesions through Regulation of Inflammatory Mediators in Vitro and in Vivo. Biochem. Biophys. Res. Commun. 2018, 498, 707-714. [CrossRef] [PubMed]

31. Lim, J.M.; Lee, B.; Min, J.H.; Kim, E.Y.; Kim, J.H.; Hong, S.; Kim, J.J.; Sohn, Y.; Jung, H.S. Effect of Peiminine on DNCB-Induced Atopic Dermatitis by Inhibiting Inflammatory Cytokine Expression in Vivo and in Vitro. Int. Immunopharmacol. 2018, 56, 135-142. [CrossRef] [PubMed]

32. Liu, Y.; Kimura, K.; Yanai, R.; Chikama, T.; Nishida, T. Cytokine, Chemokine, and Adhesion Molecule Expression Mediated by MAPKs in Human Corneal Fibroblasts Exposed to Poly(I:C). Investig. Ophthalmol. Vis. Sci. 2008, 49, 3336-3344. [CrossRef] [PubMed]

(C) 2019 by the authors. Licensee MDPI, Basel, Switzerland. This article is an open access article distributed under the terms and conditions of the Creative Commons Attribution (CC BY) license (http:/ / creativecommons.org/licenses/by/4.0/). 